\title{
PERAN GENDER ORANG TUA-REMAJA DALAM FUNGSI KELUARGA DAN KESEJAHTERAAN SUBJEKTIF REMAJA
}

\author{
Herien Puspitawati ${ }^{1 *}$, Defina ${ }^{1}$, Musthofa ${ }^{1}$, Sheila Naina ${ }^{2}$, Octaria Intan Cahayani ${ }^{1}$, Yazidah \\ Nur Rahmah ${ }^{1}$, Trisna Maulina ${ }^{1}$, Atika Windi Habsari ${ }^{1}$
}

${ }^{1}$ Departemen Ilmu Keluarga dan Konsumen, Fakultas Ekologi Manusia, IPB University, Bogor 16880, Indonesia

*)E-mail: herien_puspitawati@email.com

\begin{abstract}
Abstrak
Kemitraan orang tua dan keberfungsian keluarga merupakan faktor dominan dalam memengaruhi kesejahteraan subjektif remaja. Penelitian ini bertujuan untuk menganalisis perbedaan peran gender orang tua-remaja dalam fungsi keluarga dan kesejahteraan subjektif remaja antara remaja laki-laki dan perempuan; dan menganalisis faktor-faktor yang memengaruhi kesejahteraan subjektif remaja. Desain penelitian menggunakan cross sectional study melalui metode pengumpulan data non-probability voluntary sampling dengan analisis data menggunakan Structural Equation Modelling (SEM). Jumlah contoh penelitian sebanyak 277 keluarga yang mempunyai remaja bersekolah di SMP negeri di Kota Bogor dan tinggal bersama kedua orang tuanya. Hasil Independent T-Test menunjukkan bahwa peran gender orang tua-remaja dalam pelaksanaan aktivitas fungsi keluarga pada remaja perempuan lebih baik daripada remaja laki-laki, sedangkan tingkat kesejahteraan subjektif pada kedua kelompok remaja tidak berbeda signifikan. Variabel laten karakteristik remaja memengaruhi kesejahteraan subjektif remaja baik secara langsung maupun tidak langsung melalui peran gender orang tua-remaja. Variabel laten karakteristik keluarga juga memengaruhi kesejahteraan subjektif remaja secara tidak langsung melalui peran gender orang tua-remaja. Terakhir, variabel laten peran gender orang tua-remaja berpengaruh secara langsung terhadap kesejahteraan subjektif remaja. Dengan demikian, orang tua diharapkan mampu menjalankan fungsi keluarga pada remaja tanpa bias gender sehingga dapat meningkatkan kesejahteraan subjektif remaja.
\end{abstract}

Kata kunci: fungsi keluarga, kebahagiaan, kemitraan gender, kepuasan, remaja

\section{Parent-Adolescence's Gender Roles in Family Functions and Adolescence' Subjective Well-Being}

\begin{abstract}
The existence of parents' partnership and family functioning are the dominant factors in affecting adolescents' subjective well-being. The objectives of the study were to analyze the differences in gender-roles of parentadolescent on family functions and subjective well-being among male and female adolescents; and to analyze the factors that influence adolescents' subjective well-being. This study used a cross-sectional study design through data collection method of a voluntary non-probability sampling and using data analysis of Structural Equation Modelling (SEM). The number of research samples were 277 family with adolescents attending public middle school in Bogor City. The results of the Independent T-Test shows that gender-roles of parent-adolescent in implementation of family function activities of female adolescents were higher than that of male adolescents. However, subjective well-being among the two groups of adolescents were not significantly different. The latent variable of adolescent's characteristics influenced adolescent's subjective well-being both directly and indirectly through gender-roles of parent-adolescent. The latent variables of family characteristics also influenced adolescent's subjective well-being indirectly through gender-roles of parent-adolescent. Finally, the latent variable of gender-roles of parent-adolescent had a direct effect on adolescent's subjective well-being. Thus, parents are expected to implement family functions toward their adolescents without gender bias.
\end{abstract}

Keywords: adolescent, family functions, gender partnerships, happiness, satisfaction

\section{PENDAHULUAN}

Generasi muda memiliki peran dan fungsi yang strategis dalam pembangunan bangsa. Hasil survei Badan Pusat Statistik (2019) mencatat jumlah pemuda Indonesia sebanyak 64,19 juta jiwa. Remaja merupakan generasi penerus bangsa yang perlu diperhatikan sejak dini. Kondisi kesejahteraan subjektif remaja Indonesia belum banyak diteliti. Survei tingkat kesejahteraan anak tahun 2017 yang diukur menggunakan Indeks Komposit Kesejahteraan Anak (IKKA) Kabupaten/Kota menunjukkan secara umum hanya 67,9 persen anak 
Indonesia yang telah terpenuhi haknya serta berada pada status kesejahteraan anak tingkat menengah (KPPPA, 2017). Hasil survei ini mencakup pemenuhan hak keberlangsungan hidup, hak perlindungan, hak tumbuh kembang, hak partisipasi, dan hak identitas. Rendahnya kesejahteraan subjektif remaja disebabkan karena pengabaian dan minimnya dukungan sosial dari keluarga (Putri, 2016). Menurut World Health Organization (2014), pergolakan emosi di masa remaja dan pengabaian orang tua juga menyebabkan remaja rentan terkena gangguan mental dan setengah dari penyakit mental yang ada terjadi pada remaja dimulai dari usia 14 tahun. Data Riset Kesehatan Dasar tahun 2018 oleh Kementerian Kesehatan (2018) menyebutkan prevalensi gangguan mental emosional pada remaja sebesar 9,9 persen yang mana meningkat enam persen dibandingkan tahun 2013.

Keberfungsian keluarga merupakan salah satu komponen paling penting dalam konsep teori struktural fungsional. Keberfungsian keluarga berkaitan dengan proses kegiatan dan fungsi seluruh anggota dalam saling berkomunikasi, saling berkaitan, saling menjaga keutuhan, serta mengambil keputusan dan penyelesaian masalah bersama (Herawati et al., 2020). Keberfungsian keluarga memengaruhi kesejahteraan subjektif keluarga (Dewi \& Rahayu, 2020); sebagaimana pernyataan Botha dan Booysen (2013) yang mengemukakan bahwa fungsi keluarga yang baik akan meningkatkan kesejahteraan subjektif setiap anggotanya. Kesejahteraan subjektif merupakan evaluasi kognitif dan afektif seseorang mengenai kehidupannya terkait dengan kepuasan dan pemenuhan kebutuhan hidup (Diener, 1984). Evaluasi kognitif merujuk pada pemikiran seseorang terhadap kepuasan hidupnya secara menyeluruh, sementara evaluasi afektif atau disebut kebahagiaan berkaitan dengan suasana hati, emosi, serta perasaan seseorang (Nayana, 2013). Singkatnya, kesejahteraan subjektif merupakan persepsi seseorang secara kognitif dan afektif terhadap pengalaman hidupnya yang meliputi dua komponen, yaitu secara kognitif mengenai kepuasan dan secara afektif mengenai kebahagiaan.

Keunikan tulisan ini adalah mengaitkan teori struktural fungsional dan teori gender yang belum banyak diteliti. Kombinasi analisis teori struktural fungsional terkait fungsi keluarga dilihat dari pandangan peran gender orangtuaanak. Anak pada penelitian ini adalah anak remaja yang merupakan masa pencarian identitas (Diananda, 2018). Oleh karenanya, remaja rentan menemui permasalahan baru, utamanya masalah yang berkaitan dengan kognitif, emosi, spiritualitas, serta identitas yang dapat memengaruhi kesejahteraan subjektifnya (Dewi, 2014). Berbagai masalah di sekolah, perbedaan argumen antara anak dengan orang tua, serta hubungan dengan teman sebaya dapat menjadi sumber stres remaja (Hastuti \& Baiti, 2019). Dampaknya, konflik dan kesulitan yang dihadapi remaja tersebut dapat menurunkan kesejahteraan subjektifnya (Raharja \& Indati, 2018).

Kesejahteraan subjektif terdiri atas kebahagiaan dan kepuasan. Pada remaja, keberadaan orang tua dan keberfungsian keluarga merupakan faktor terbesar terciptanya kebahagiaan dan kepuasan hidup (Prasisti, 2016). Keberfungsian keluarga yang tanggap dan saling terlibat dalam aspek kasih sayang, komunikasi, dan peran dapat memrediksi masalah remaja, sementara disfungsi keluarga dapat meningkatkan gejala psikis remaja (Stanescu \& Romer, 2011). Namun, orang tua memiliki tantangan dalam melaksanakan fungsi keluarga seperti minimnya pengetahuan distribusi peran gender dan kesibukan ayah-ibu yang sama-sama bekerja (Herawati et al., 2020). Kesibukan orang tua yang bekerja bisa saja mengganggu pembagian peran gender dan memicu konflik. Padahal, perlu adanya pembagian peran gender untuk pendistribusian tugas dan kerja sama agar pelaksanaan fungsi keluarga berjalan optimal (Puspitawati, 2017), terutama bagi ibu.

Kelelahan ibu akibat bekerja di publik dan harus tetap mengurusi urusan domestik menjadi pemicu terjadinya konflik kerja-keluarga karena ayah tidak ikut bekerja sama membantu menjalankan urusan domestik juga (Maintier, Joulain, \& Le Floc'h, 2011). Konflik keluarga dapat merugikan anak karena anak bisa menjadi korban kekerasan. Selama pandemi Covid-19, Komisi Nasional Anti Kekerasan terhadap Perempuan mencatat tingkat kekerasan domestik mencapai 75 persen (11.105 kasus) dengan rincian kekerasan fisik sebanyak 4.783 kasus (43\%), kekerasan seksual sebanyak 2.807 kasus (25\%), kekerasan psikis sebanyak 2.056 kasus (19\%), dan kekerasan ekonomi sebanyak 1.459 kasus $(13 \%)$ (Susiana, 2020). Jika hal ini terus terjadi, keberfungsian keluarga tidak dapat dilaksanakan dan mengganggu kesejahteraan subjektif remaja. 
Pada dasarnya, orang tua sangat dibutuhkan remaja untuk mendapatkan fungsi keluarga seperti perlindungan, kasih sayang, dan sosialisasi pendidikan. Keluarga yang membangun komunikasi secara terbuka dan positif dapat memberikan kepuasan kepada remaja (Bandura et al., 2011). Kerja sama dalam pengambilan keputusan di setiap permasalahan memengaruhi kesejahteraan keluarga secara keseluruhan (Sultana, Hed, \& Leh, 2013). Kesejahteraan keluarga yang setara dan berkeadilan gender dapat tercipta dengan adanya kemitraan serta relasi gender yang harmonis dalam keluarga (Aziz, 2017).

Analisis gender perlu dilakukan terhadap kesejahteraan subjektif antara remaja laki-laki dan perempuan. Menurut Megawangi (2014) laki-laki dan perempuan berbeda secara karakteristik, yaitu laki-laki memiliki sifat maskulin, sementara perempuan memiliki sifat feminim. Remaja laki-laki cenderung lebih proaktif dan reaktif dengan hubungan teman sebaya, sedangkan remaja perempuan lebih agresif kepada perilaku yang berkaitan dengan relasi romantis (Saputra, Hanifah, \& Widagdo, 2017). Konflik dan kesulitan yang remaja hadapi tersebut dapat menurunkan kepuasan hidupnya (Raharja \& Indati, 2018).

Kajian mengenai fungsi keluarga, peran gender, dan kesejahteraan keluarga sudah banyak dilakukan sebelumnya, di antaranya ada penelitian yang mengaitkan fungsi keluarga dengan perlindungan anak (Fatimaningsih, 2013), penyesuaian perkawinan (Ningsih \& Herawati, 2017), peran gender dan pemeliharaan lingkungan mikro dengan kesejahteraan subjektif keluarga (Rahma, Puspitawati, \& Herawati, 2015), dukungan sosial dan interaksi ibu-remaja dengan kesejahteraan subjektif remaja (Wijayanti, Sunarti, \& Krisnatuti, 2020), dan beberapa faktor yang dapat memengaruhi terlaksananya fungsi keluarga di Indonesia (Herawati et al., 2020). Nayana (2013) juga menemukan bahwa fungsi keluarga yang berjalan dengan baik menjadi salah satu faktor penentu kondisi kesejahteraan seseorang, khususnya di masa remaja. Dengan demikian, dapat dikatakan bahwa selama ini sudah banyak penelitian tentang fungsi keluarga dan kesejahteraan remaja tetapi belum ada penelitian serupa yang mengaitkan dengan peran gender orang tua dan remaja dalam keberfungsi keluarga dengan kesejahteraan subjektif remaja. Berdasarkan rumusan paparan di atas, maka tujuan penelitian ini adalah menganalisis perbedaan peran gender orang tua-remaja dalam fungsi keluarga dan kesejahteraan subjektif remaja antara remaja laki-laki dan perempuan; dan menganalisis faktor-faktor yang memengaruhi kesejahteraan subjektif remaja.

\section{METODE}

Penelitian ini menggunakan desain crosssectional study dengan pendekatan penelitian kuantitatif. SMP negeri di Kota Bogor dipilih secara purposive sebagai lokasi penelitian karena 62,44 persen siswa SMP negeri di Kota Bogor dalam kategori bermasalah (Wendari, Badrujaman, \& Sismiati, 2016). Responden yang berpartisipasi merupakan siswa/i kelas VII, VIII, dan IX dan tinggal bersama kedua orang tuanya agar dapat melihat kemitraan gender ayah dan ibu.

Teknik penarikan contoh menggunakan nonprobability voluntary sampling melalui survei daring akibat adanya pandemi Covid-19 sehingga tidak memungkinkan untuk bertemu langsung dengan responden (remaja). Jumlah contoh penelitian ini sebanyak 277 remaja dengan rincian 94 orang berjenis kelamin lakilaki dan 183 orang berjenis kelamin perempuan. Pengumpulan data penelitian dilakukan selama sebelas hari antara bulan Maret hingga April tahun 2020.

Penelitian ini menggunakan data primer melalui pengisian Google Form oleh remaja (selfadministered) yang meliputi karakteristik remaja, karakteristik keluarga, peran gender dalam fungsi keluarga, dan kesejahteraan subjektif remaja. Karakteristik remaja terdiri dari usia dan jenis kelamin. Karakteristik keluarga terdiri dari usia ayah, usia ibu, pendidikan ayah, pendidikan ibu, status pekerjaan ayah, status pekerjaan ibu, pendapatan keluarga, dan besar keluarga. Pengelompokkan usia ayah dan ibu berdasarkan Hurlock (1980), yaitu dewasa awal (18-40 tahun), dewasa madya (41-60 tahun), dan dewasa akhir (>60 tahun). Pengelompokan besar keluarga mengacu pada Badan Kependudukan dan Keluarga Berencana Nasional (BKKBN, 2005), yaitu keluarga kecil ( $\leq 4$ orang), keluarga sedang (5-7 orang), dan keluarga besar ( $>7$ orang). Variabel utama pertama dalam penelitian ini yaitu peran gender-remaja dalam fungsi keluarga yang terdiri dari dimensi intensitas aktivitas dan kemitraan gender. Variabel utama kedua adalah kesejahteraan subjektif remaja yang terdiri dari dimensi kepuasan dan kebahagiaan.

Peran gender orang tua-remaja merupakan variabel komposit dari intensitas aktivitas antara orang tua dengan remaja dan kemitraan gender antara ayah dan ibu dalam menjalankan aktivitas delapan fungsi keluarga. Variabel 
peran gender orang tua-remaja merupakan komposit dari dimensi intensitas aktivitas dan kemitraan gender yang dilaksanakan dalam 8 (delapan) fungsi. Peran gender orang tuaremaja dilakukan bertujuan untuk mendistribusikan tugas dengan baik agar efisiensi dan keseimbangan sistem dalam keluarga tercapai (Puspitawati, 2017). Variabel peran gender orang tua-remaja dalam fungsi keluarga terdiri dari 82 pertanyaan dimensi intensitas aktivitas dan kemitraan gender dengan nilai Cronbach's alpha sebesar 0,954.

Kuesioner dimensi intensitas aktivitas fungsi keluarga digunakan untuk melihat seberapa besar frekuensi aktivitas delapan fungsi keluarga diterima remaja dari orang tuanya. Kuesioner ini merupakan modifikasi dari konsep dan nilai-nilai dasar fungsi keluarga BKKBN (2013) dan kuesioner fungsi keluarga yang disusun oleh Putri, Krisnatuti, dan Puspitawati (2019). Kuesioner ini terdiri dari 41 pertanyaan dengan nilai Cronbach's alpha 0,930. Jawaban pertanyaan menggunakan skala likert $1=$ tidak pernah, 2=jarang, 3=cukup sering, dan $4=$ sering sekali. Pada penelitian ini dimensi intensitas aktivitas dilaksanakan dalam 8 (delapan) fungsi.

Kuesioner dimensi kemitraan gender fungsi keluarga digunakan untuk melihat seberapa seimbang kerja sama ayah-ibu dalam menjalankan aktivitas delapan fungsi keluarga. Kuesioner ini dimodifikasi berdasarkan konsep dan nilai-nilai dasar fungsi keluarga BKKBN (2013) dan kuesioner fungsi keluarga yang disusun oleh Putri et al. (2019). Kemudian, skor jawaban menggunakan kuesioner Measurements of Gender Equality Practices within Family (Krzaklewska, 2014) dan dimodifikasi sesuai kebutuhan. Kuesioner ini memiliki 41 pertanyaan dengan nilai Cronbach's alpha 0,930. Pada penelitian ini dimensi kemitraan gender dilaksanakan dalam 8 (delapan) fungsi. Skor jawaban menggunakan skala Likert 1=ayah saja, 2=ayah dominan, 3=ayah dan ibu setara, 4=ibu dominan, 5=ibu saja, dan $6=$ tidak pernah. Selanjutnya, jawaban di-recode score untuk melihat kerja sama peran gender menjadi $0=$ tidak pernah (skor awal $6=0$ ), $1=$ ayah/ibu saja (skor awal $1=1 ; 5=1$ ), $2=$ ayah/ibu dominan (skor awal 2=2; 4=2), dan $3=$ ayah dan ibu setara (skor awal 3=3). Penjelasan dimensi kemitraan gender mengacu pada Puspitawati (2018) yang dikategorikan ke dalam tiga tingkatan: (1) kerja sama yang hanya dilakukan oleh salah satu pihak saja, yaitu ayah saja atau ibu saja, (2) dominan oleh salah satu pihak, dana (3) seimbang yang artinya ayah dan ibu bekerja sama satu sama lain dalam menerapkan delapan fungsi keluarga pada remaja.

Kesejahteraan subjektif remaja dalam penelitian ini merupakan evaluasi kognitif berupa kepuasan, afektif, dan kebahagiaan. Variabel kesejahteraan subjektif memiliki 20 pertanyaan yang terdiri dari pertanyaan dimensi kepuasan dan kebahagiaan dengan nilai Cronbach's alpha 0,895. Semakin tinggi skor artinya semakin tinggi kesejahteraan subjektif yang dirasakan oleh remaja.

Kuesioner dimensi kebahagiaan remaja digunakan untuk melihat evaluasi afektif atau emosi remaja berupa perasaan senang atau bahagia. Kuesioner ini mengacu pada Oxford Happiness Questionnaire (Hills \& Argyle, 2002) yang terdiri dari sepuluh pertanyaan dan telah disesuaikan dengan kondisi remaja. Kategori jawaban menggunakan skala Likert 1=sangat tidak setuju, 2=kurang setuju, 3=cukup setuju, dan 4=sangat setuju dengan nilai Cronbach's alpha 0,745. Semakin tinggi skor bermakna remaja semakin bahagia dengan hidupnya.

Kuesioner dimensi kepuasan remaja berguna untuk melihat evaluasi kognitif remaja berupa kepuasan hidup. Kuesioner ini mengacu pada Family Satisfaction Scale (Olson, 2004) yang terdiri dari sepuluh pertanyaan. Jawaban dikategorikan menggunakan skala likert 1 =sangat tidak puas, $2=$ tidak puas, $3=$ cukup puas, $4=$ puas, dan $5=$ sangat puas dengan nilai Cronbach's alpha 0,893.

Pengolahan data dalam penelitian ini menggunakan Statistical Package for Social Science (SPSS) dan uji Structural Equation Modeling (SEM) software LISREL. Analisis data meliputi analisis deskriptif untuk mengetahui sebaran karakteristik remaja, karakteristik keluarga, peran gender orang tua dan remaja dalam fungsi keluarga yang meliputi dimensi intensitas aktivitas dan kemitraan gender, serta kesejahteraan subjektif remaja yang meliputi dimensi kepuasan dan kebahagiaan. Uji beda menggunakan Independent T-Test untuk mengetahui perbedaan variabel penelitian berdasarkan jenis kelamin remaja. Uji SEM digunakan untuk menganalisis faktor-faktor yang memengaruhi kesejahteraan subjektif remaja. Pengategorian data menggunakan cut off Sustainable Livelihood Approach (Silitonga, Puspitawati, \& Muflikhati, 2018) dengan ketentuan rendah $(\leq 50,00)$, sedang $(50,01$ $75,00)$, dan tinggi $(>75,00)$. 
Tabel 1 Analisis gender tentang karakteristik keluarga remaja laki-laki dan perempuan $(n=277)$

\begin{tabular}{|c|c|c|c|c|}
\hline \multirow[b]{2}{*}{ Variabel } & \multicolumn{2}{|c|}{ Rata-rata } & \multirow{2}{*}{$\begin{array}{c}\text { Indepen } \\
\text { dent T- } \\
\text { Test }\end{array}$} & \multirow{2}{*}{$\begin{array}{l}\text { Signifi } \\
\text { kan } \\
\text { (p) }\end{array}$} \\
\hline & $\begin{array}{l}\text { Laki- } \\
\text { laki }\end{array}$ & $\begin{array}{c}\text { Perem } \\
\text { puan }\end{array}$ & & \\
\hline $\begin{array}{l}\text { Usia Ayah } \\
\text { (tahun) }\end{array}$ & 47,54 & 46,80 & 1,010 & 0,313 \\
\hline $\begin{array}{l}\text { Usia lbu } \\
\text { (tahun) }\end{array}$ & 43,07 & 43,15 & $-0,104$ & 0,917 \\
\hline $\begin{array}{l}\text { Pendidikan } \\
\text { Ayah } \\
\text { (tahun) }\end{array}$ & 13,18 & 13,12 & 0,134 & 0,893 \\
\hline $\begin{array}{l}\text { Pendidikan } \\
\text { lbu (tahun) }\end{array}$ & $\begin{array}{r}13,0 \\
3\end{array}$ & 12,51 & 1,252 & 0,212 \\
\hline $\begin{array}{l}\text { Status } \\
\text { Pekerjaan } \\
\text { Ayah } \\
\text { ( } 0=\text { tidak } \\
\text { bekerja; } 1=\text { b } \\
\text { ekerja) }\end{array}$ & 0,98 & 0,97 & 0,303 & 0,762 \\
\hline $\begin{array}{l}\text { Status } \\
\text { Pekerjaan } \\
\text { lbu }(0=\text { tidak } \\
\text { bekerja; } 1=b \\
\text { ekerja) }\end{array}$ & 0,31 & 0,24 & 1,185 & 0,237 \\
\hline $\begin{array}{l}\text { Jumlah } \\
\text { Anggota } \\
\text { Keluarga } \\
\text { (orang) }\end{array}$ & 5,02 & 4,79 & 1,433 & 0,153 \\
\hline $\begin{array}{l}\text { Total } \\
\text { Pendapatan } \\
\text { Keluarga } \\
\text { (Rp/bulan) }\end{array}$ & $\begin{array}{r}7.245 . \\
798\end{array}$ & $\begin{array}{r}6.856 .0 \\
10\end{array}$ & 0,357 & 0,721 \\
\hline
\end{tabular}

\section{HASIL}

\section{Karakteristik Remaja}

Responden yang terlibat dalam penelitian adalah 277 remaja SMP, yaitu 33,9 persen lakilaki dan 66,1 persen perempuan. Rata-rata usia kedua kelompok remaja berada pada kategori remaja awal (13-16 tahun), yaitu 14,29 tahun untuk remaja laki-laki dan 14,19 tahun untuk remaja perempuan. Berdasarkan sebaran remaja dalam penelitian ini, sebesar 64,9 persen remaja laki-laki dan 65,0 persen remaja perempuan berada di jenjang Kelas IX.

\section{Karakteristik Keluarga}

Berdasarkan usia, ibu dan ayah memiliki ratarata usia yang terkategori dewasa madya (4160 tahun). Pendidikan yang ditempuh oleh ibu dan ayah rata-rata di atas dua belas tahun atau sampai tingkat perguruan tinggi. Berdasarkan status pekerjaan, hasil analisis data memperlihatkan bahwa rata-rata status pekerjaan ayah remaja laki-laki dan perempuan adalah 0,98 dan 0,97 yang maknanya adalah bahwa sebagian besar ayah remaja laki-laki dan perempuan berstatus bekerja. Rata-rata besar keluarga kedua kelompok remaja terkategori keluarga sedang (5-7 orang) dengan rata-rata pendapatan per bulan sudah di atas Upah Minimum Kota (UMK) Kota Bogor tahun 2020 yaitu Rp4.169.806,58. Pada karakteristik keluarga tidak ditemukan perbedaan yang signifikan pada masing-masing variabel, artinya secara umum remaja laki-laki dan perempuan berasal dari latar belakang keluarga yang hampir sama (Tabel 1).

\section{Peran Gender Orang Tua-Remaja dalam Fungsi Keluarga}

Intensitas Aktivitas dalam Fungsi Keluarga. Hasil penelitian menunjukkan bahwa capaian intensitas aktivitas fungsi keluarga berada pada rentang kategori sedang hingga tinggi. Secara keseluruhan, orang tua sudah cukup sering dalam menerapkan aktivitas delapan fungsi keluarga pada kedua kelompok remaja. Namun demikian, ditemukan bahwa orang tua lebih sering melaksanakan aktivitas delapan fungsi keluarga pada remaja perempuan daripada remaja laki-laki dengan perbedaan yang sangat signifikan (Tabel 2).

Kemitraan Gender dalam Fungsi Keluarga. Secara keseluruhan, kemitraan gender ayah dan ibu sudah seimbang dalam menjalankan aktivitas delapan fungsi keluarga pada remaja, baik perempuan maupun laki-laki. Selanjutnya ditemukan bahwa kemitraan gender ayah dan ibu dalam menjalankan delapan fungsi keluarga tidak berbeda nyata antara remaja perempuan dan laki-laki.

Peran Gender Orang Tua-Remaja dalam Fungsi Keluarga. Secara keseluruhan orang tua lebih banyak melaksanakan aktivitas delapan fungsi keluarga dengan kerja sama yang seimbang pada kelompok remaja perempuan daripada laki-laki. Hal ini telihat dari hasil uji beda yang menunjukkan perbedaan signifikan dan dari nilai total peran gender remaja perempuan lebih tinggi dibandingkan laki-laki.

\section{Kesejahteraan Subjektif Remaja}

Kepuasan. Rata-rata skor kepuasan remaja laki-laki dan perempuan terkategori sedang dan tidak berbeda signifikan yang berarti kedua kelompok remaja sudah merasa cukup puas. Namun, remaja laki-laki merasa lebih puas dalam mengatasi stres/tekanan/konflik dibandingkan remaja perempuan. 
Tabel 2 Presentase peran gender orang tua-remaja dalam fungsi keluarga, dimensi, dan Independent

\begin{tabular}{|c|c|c|c|c|c|c|c|c|c|c|}
\hline \multirow{2}{*}{ Variabel } & \multicolumn{3}{|c|}{ Persen Laki-laki (L) } & \multicolumn{3}{|c|}{$\begin{array}{l}\text { Persen Perempuan } \\
\text { (P) }\end{array}$} & \multicolumn{2}{|c|}{ Rata-rata } & \multirow{2}{*}{$\begin{array}{c}\text { Tes } \\
\text { Indepen- } \\
\text { dent }\end{array}$} & \multirow{2}{*}{$\begin{array}{l}\text { Sig. } \\
(p)\end{array}$} \\
\hline & $\mathrm{R}$ & $\mathrm{S}$ & $T$ & $\mathrm{R}$ & $S$ & $T$ & $\mathrm{~L}$ & $P$ & & \\
\hline \multicolumn{11}{|c|}{ Dimensi intensitas aktivitas } \\
\hline $\begin{array}{l}\text { Fungsi } \\
\text { keagamaan } \\
\text { (indeks) }\end{array}$ & 3,2 & 29,8 & 67,0 & 1,6 & 23,0 & 75,4 & 80,35 & 83,57 & $-1,785$ & $0,075^{+}$ \\
\hline $\begin{array}{l}\text { Fungsi sosial } \\
\text { budaya (indeks) }\end{array}$ & 8,5 & 66,0 & 25,5 & 9,8 & 53,6 & 36,6 & 66,93 & 70,94 & $-1,780$ & $0,076^{+}$ \\
\hline $\begin{array}{l}\text { Fungsi cinta } \\
\text { kasih (indeks) }\end{array}$ & 5,3 & 39,4 & 55,3 & 5,5 & 36,1 & 58,5 & 77,02 & 77,74 & $-0,347$ & 0,729 \\
\hline $\begin{array}{l}\text { Fungsi } \\
\text { reproduksi } \\
\text { (indeks) }\end{array}$ & 57,4 & 33,0 & 9,6 & 22,4 & 45,4 & 32,2 & 66,93 & 70,94 & $-7,108$ & $0,000^{* *}$ \\
\hline $\begin{array}{l}\text { Fungsi } \\
\text { perlindungan } \\
\text { (indeks) }\end{array}$ & 1,1 & 34,0 & 64,9 & 0,5 & 17,5 & 82,0 & 80,73 & 85,97 & $-3,139$ & $0,002^{* *}$ \\
\hline $\begin{array}{l}\text { Fungsi } \\
\text { sosialisasi \& } \\
\text { pendidikan } \\
\text { (indeks) }\end{array}$ & 10,6 & 51,1 & 38,3 & 2,7 & 51,4 & 45,9 & 69,56 & 73,89 & -2.200 & $0,029^{*}$ \\
\hline $\begin{array}{l}\text { Fungsi ekonomi } \\
\text { (indeks) }\end{array}$ & 12,8 & 50,0 & 37,2 & 6,6 & 47,5 & 45,9 & 71,19 & 74,45 & $-1,388$ & 0,166 \\
\hline $\begin{array}{l}\text { Fungsi } \\
\text { pembinaan } \\
\text { lingkungan } \\
\text { (indeks) }\end{array}$ & 25,5 & 45,7 & 28,7 & 16,9 & 49,2 & 33,9 & 61,64 & 65,79 & $-1,682$ & $0,094^{+}$ \\
\hline $\begin{array}{l}\text { Delapan fungsi } \\
\text { (indeks) }\end{array}$ & 6,4 & 61,7 & 31,9 & 3,8 & 44,3 & 51,9 & 69,01 & 74,79 & 0,400 & $0,001^{* *}$ \\
\hline \multicolumn{11}{|c|}{ Dimensi kemitraan gender } \\
\hline $\begin{array}{l}\text { Fungsi } \\
\text { keagamaan } \\
\text { (indeks) }\end{array}$ & 3,2 & 17,0 & 79,8 & 4,4 & 23,0 & 72,7 & 84,46 & 83,78 & 0,345 & 0,731 \\
\hline $\begin{array}{l}\text { Fungsi sosial } \\
\text { budaya (indeks) }\end{array}$ & 10,6 & 36,2 & 53,2 & 6,6 & 43,2 & 50,3 & 75,35 & 77,14 & $-0,684$ & 0,495 \\
\hline $\begin{array}{l}\text { Fungsi cinta } \\
\text { kasih (indeks) }\end{array}$ & 4,3 & 20,2 & 75,5 & 2,2 & 15,8 & 82,0 & 84,26 & 88,34 & $-1,960$ & $0,052^{+}$ \\
\hline $\begin{array}{l}\text { Fungsi } \\
\text { reproduksi } \\
\text { (indeks) }\end{array}$ & 44,7 & 17,0 & 38,3 & 34,4 & 42,1 & 23,5 & 54,18 & 57,66 & $-0,864$ & 0,389 \\
\hline $\begin{array}{l}\text { Fungsi } \\
\text { perlindungan } \\
\text { (indeks) }\end{array}$ & 5,3 & 34,0 & 60,6 & 5,5 & 31,7 & 62,8 & 76,30 & 77,41 & 0,822 & 0,597 \\
\hline $\begin{array}{l}\text { Fungsi } \\
\text { sosialisasi \& } \\
\text { pendidikan } \\
\text { (indeks) }\end{array}$ & 6,4 & 28,7 & 64,9 & 3,8 & 24,6 & 71,6 & 77,89 & 80,44 & 0,057 & 0,223 \\
\hline $\begin{array}{l}\text { Fungsi ekonomi } \\
\text { (indeks) }\end{array}$ & 12,8 & 29,8 & 57,4 & 10,9 & 39,9 & 49,2 & 76,60 & 76,64 & $-0,015$ & 0,988 \\
\hline $\begin{array}{l}\text { Fungsi } \\
\text { pembinaan } \\
\text { lingkungan } \\
\text { (indeks) }\end{array}$ & 6,4 & 40,4 & 53,2 & 4,4 & 35,5 & 60,1 & 74,41 & 77,23 & $-1,279$ & 0,203 \\
\hline $\begin{array}{l}\text { Delapan fungsi } \\
\text { (indeks) }\end{array}$ & 6,4 & 61,7 & 31,9 & 3,8 & 44,3 & 51,9 & 75,46 & 77,43 & $-1,013$ & 0,313 \\
\hline \multicolumn{11}{|c|}{ Peran gender orang tua } \\
\hline $\begin{array}{l}\text { Fungsi } \\
\text { keagamaan } \\
\text { (indeks) }\end{array}$ & 2,1 & 16,0 & 81,9 & 2,2 & 18,0 & 79,8 & 82,41 & 83,67 & $-0,815$ & 0,416 \\
\hline
\end{tabular}


(Lanjutan) Tabel 2 Presentase peran gender orang tua-remaja dalam fungsi keluarga, dimensi, dan Independent T-Test $(\mathrm{n}=277)$

\begin{tabular}{|c|c|c|c|c|c|c|c|c|c|c|}
\hline \multirow[t]{2}{*}{ Variabel } & \multicolumn{3}{|c|}{ Persen Laki-laki (L) } & \multicolumn{3}{|c|}{$\begin{array}{c}\text { Persen Perempuan } \\
(\mathrm{P})\end{array}$} & \multicolumn{2}{|c|}{ Rata-rata } & \multirow{2}{*}{$\begin{array}{c}\text { Tes } \\
\text { Indepen- } \\
\text { dent }\end{array}$} & \multirow{2}{*}{$\begin{array}{l}\text { Sig. } \\
(p)\end{array}$} \\
\hline & $\mathrm{R}$ & $\mathrm{S}$ & $\mathrm{T}$ & $\mathrm{R}$ & $\mathrm{S}$ & $\mathrm{T}$ & L & $\mathrm{P}$ & & \\
\hline $\begin{array}{l}\text { Fungsi sosial } \\
\text { budaya (indeks) }\end{array}$ & 7,4 & 52,1 & 40,4 & 6,0 & 47,0 & 47,0 & 71,14 & 74,04 & $-1,454$ & 0,147 \\
\hline $\begin{array}{l}\text { Fungsi cinta } \\
\text { kasih (indeks) }\end{array}$ & 4,3 & 22,3 & 73,4 & 1,1 & 23,0 & 76,0 & 80,64 & 83,04 & $-1,403$ & 0,162 \\
\hline $\begin{array}{l}\text { Fungsi } \\
\text { reproduksi } \\
\text { (indeks) }\end{array}$ & 44,7 & 36,2 & 19,1 & 25,1 & 51,9 & 23,0 & 48,93 & 61,23 & $-3,863$ & $0,000^{* *}$ \\
\hline $\begin{array}{l}\text { Fungsi } \\
\text { perlindungan } \\
\text { (indeks) }\end{array}$ & 2,1 & 44,7 & 53,2 & 1,1 & 26,8 & 72,1 & 78,52 & 81,69 & $-1,935$ & $0,054^{+}$ \\
\hline $\begin{array}{l}\text { Fungsi } \\
\text { sosialisasi \& } \\
\text { pendidikan } \\
\text { (indeks) }\end{array}$ & 7,4 & 43,6 & 28,9 & 1,6 & 41,5 & 56,8 & 73,72 & 77,17 & $-1,805$ & $0,073^{+}$ \\
\hline $\begin{array}{l}\text { Fungsi ekonomi } \\
\text { (indeks) }\end{array}$ & 11,7 & 37,2 & 51,1 & 7,1 & 43,7 & 49,2 & 73,89 & 75,55 & $-0,743$ & 0,458 \\
\hline $\begin{array}{l}\text { Fungsi } \\
\text { pembinaan } \\
\text { lingkungan } \\
\text { (indeks) }\end{array}$ & 14,9 & 52,1 & 33,0 & 7,1 & 55,2 & 37,7 & 68,03 & 71,51 & $-1,638$ & 0,103 \\
\hline $\begin{array}{l}\text { Delapan fungsi } \\
\text { (indeks) }\end{array}$ & 6,4 & 40,4 & 53,2 & 2,7 & 39,3 & 57,9 & 72,24 & 76,11 & $-2,492$ & $0,013^{*}$ \\
\hline
\end{tabular}

Kebahagiaan. Rataan skor kebahagiaan remaja laki-laki dan perempuan terkategori tinggi dan tidak berbeda signifikan. Namun, secara khusus remaja perempuan lebih mudah tertawa, dan tidak gelisah dibandingkan remaja laki-laki (Tabel 3).

Kesejahteraan Subjektif. Kesejahteraan subjektif remaja laki-laki dan perempuan terkategori tinggi dan tidak berbeda signifikan. Artinya, secara keseluruhan kedua kelompok remaja sudah memiliki penilaian kognitif berupa kepuasan dan kebahagiaan yang baik dalam hidupnya.

\section{Analisis Structural Equation Modelling (SEM)}

Model SEM berikut ini menyajikan pendekatan model holistik yang menggambarkan keterkaitan antarsub-sistem dalam sistem keluarga yang terdiri atas ayah, ibu dan remaja. Gambar 1 menjelaskan model empiris faktorfaktor yang memengaruhi kesejahteraan subjektif remaja.

Tabel 3 Presentase kategori kesejahteraan subjektif remaja laki-laki dan perempuan, dimensi, serta Independent T-Test $(\mathrm{n}=277)$

\begin{tabular}{|c|c|c|c|c|c|c|}
\hline \multirow{2}{*}{ Variabel } & \multicolumn{3}{|c|}{ Proporsi Laki-laki (L) } & \multicolumn{3}{|c|}{ Proporsi Perempuan (P) } \\
\hline & Rendah & Sedang & Tinggi & Rendah & Sedang & Tinggi \\
\hline Dimensi Kepuasan (indeks) & 6,4 & 43,6 & 50,0 & 9,8 & 39,3 & 50,8 \\
\hline Rata-rata (SD) & \multicolumn{3}{|c|}{$74,70(15,678)$} & \multicolumn{3}{|c|}{$73,11(17,135)$} \\
\hline Uji Beda Independen (t, p) & \multicolumn{6}{|c|}{$t=0,754 \quad(p=0,452)$} \\
\hline Dimensi Kebahagiaan (indeks) & 1,1 & 30,9 & 68,1 & 1,6 & 23,0 & 75,4 \\
\hline Rata-rata (SD) & & $80,81(11,980)$ & & & $81,20(12,714)$ & \\
\hline Uji Beda Independen (t, p) & \multicolumn{6}{|c|}{$t=0,244 \quad(p=0,807)$} \\
\hline $\begin{array}{l}\text { Kesejahteraan Subjektif } \\
\text { Remaja (indeks) }\end{array}$ & 1,1 & 36,2 & 62,8 & 4,4 & 33,3 & 62,3 \\
\hline Rata-rata (SD) & \multirow{2}{*}{\multicolumn{3}{|c|}{$77,32(12,764)$}} & \multirow{2}{*}{\multicolumn{3}{|c|}{$76,58(13,838)$}} \\
\hline Independent T-Test (t, $\mathrm{p})$ & & & & & & \\
\hline
\end{tabular}

Keterangan: ${ }^{+}=$signifikan $\mathrm{p}<0,1 ;{ }^{*}=$ signifikan $\mathrm{p}<0,05 ;{ }^{* *}=$ signifikan $\mathrm{p}<0,01 ; \mathrm{R}=$ rendah $(\leq 50,00), \mathrm{S}=$ sedang $(50,01-75,00)$, dan $T=$ tinggi $(>75,00)$ 
Tabel 4 Hasil dekomposisi efek dari Gambar 1

\begin{tabular}{|c|c|c|c|}
\hline Variabel & TE & $\mathrm{DE}$ & IE \\
\hline \multicolumn{4}{|c|}{ Kesejahteraan subjektif remaja $\eta_{4}$} \\
\hline$\eta_{1}$ & 0,00 & $\begin{array}{c}- \\
0,15^{\star}\end{array}$ & $0,15^{\star}$ \\
\hline$\eta_{2}$ & 0,05 & $-0,40$ & $0,09^{*}$ \\
\hline$\eta_{3}$ & $0,63^{*}$ & $0,63^{*}$ & 0,00 \\
\hline
\end{tabular}

Keterangan: ${ }^{+}=$signifikan $\mathrm{p}<0,1 ;{ }^{*}=$ signifikan $\mathrm{p}<0,05 ;{ }^{* *}=$ signifikan $p<0,01 ; \mathrm{TE}=$ Total Effect; $\mathrm{DE}=$ Direct Effect; $\mathrm{IE}=$ Indirect Effect

Hasil menunjukkan nilai Chi-Square, Goodness of Fit Index (GFI), Comparative of Fit Index (CFI), dan Root Mean Square Error (RMSE) berturut-turut adalah 51,$45 ; 0,95 ; 0,91$; dan 0,11 . Dengan demikian, model SEM pada Gambar 1 dapat dikatakan cocok (fit) dengan data yang dikumpulkan. Selanjutnya, diketahui pula angka item loading untuk variabel laten yaitu: (1) karakteristik remaja yang dicerminkan oleh satu indikator jenis kelamin adalah 0,89 $(p<0,01)$, (2) karakteristik keluarga yang dicerminkan oleh indikator pendidikan ayah-ibu adalah $0,89(p<0,01)$ dan pendapatan keluarga adalah $0,42(p<0,01),(3)$ peran gender orang tua-remaja yang dicerminkan oleh indikator intensitas aktivitas adalah $0,89(p<0,01)$ dan kemitraan gender adalah 0,67 ( $p<0,01)$, dan (4) kesejahteraan subjektif remaja yang dicerminkan oleh indikator kebahagiaan adalah $0,89(p<0,01)$ dan kepuasaan adalah 0,73 $(p<0,01)$.

Angka item loading yang membentuk keempat variabel laten di atas cukup konsisten dengan tingkat konsistensi internal (reliabilitas) yang dapat diterima. Tabel 4 menyajikan dekomposisi efek yang memberikan gambaran efek langsung dan tidak langsung serta secara total. Tabel dekomposisi efek menjelaskan faktor-faktor yang berpengaruh secara langsung dan tidak langsung terhadap variabel laten kesejahteraan subjektif remaja dengan urutan derajat pengaruh. Pertama, secara langsung oleh variabel laten peran gender orang tua-remaja (sebesar $0,63^{2}$ atau $39,69 \%$ ). Kedua, secara langsung oleh variabel laten karakteristik remaja (sebesar $-0,15^{2}$ atau $2,25 \%$ ) dan secara tidak langsung oleh variabel laten karakteristik remaja (sebesar $0,15^{2}$ atau $2,25 \%)$. Ketiga, secara tidak langsung oleh variabel laten karakteristik keluarga (sebesar $0,09^{2}$ atau $0,81 \%$ ).

Adapun analisis jalur-jalur rangkaian faktorfaktor yang berpengaruh secara langsung dan tidak langsung terhadap variabel laten kesejahteraan subjektif remaja adalah: (1) terdapat satu jalur langsung-1 dari $\eta_{1}$ (karakteristik remaja) ke $\eta_{4}$ (kesejahteraan subjektif remaja) dengan koefisien beta $-0,15^{*}$ $(p<0,05)$ atau $(0,15)^{2}$ atau 2,25 persen. Maknanya, variabel laten kesejahteraan subjektif remaja dijelaskan secara langsung sebesar 2,25 persen oleh variabel laten karakteristik remaja. (2) terdapat 2 jalur tidak langsung meliputi: (a) jalur tidak langsung-1 dari $\eta_{1}$ (karakteristik remaja) yang dimediasi oleh $\eta_{3}$ (peran gender orang tua-remaja) terus ke $\eta_{4}$ (kesejahteraan subjektif remaja) dengan besar efek tidak langsung sebesar $\beta 31 \times \beta 43$ atau $(0,24) \times(0,63)$ sama dengan 0,1512 . Maknanya, variabel laten kesejahteraan subjektif remaja dijelaskan secara tidak langsung sebesar 15,12 persen oleh variabel laten karakteristik remaja yang dimediasi oleh peran gender orang tua-remaja, dan jalur tidak langsung-2 dari $\eta_{2}$ (karakteristik keluarga) yang dimediasi oleh $\eta_{3}$ (peran gender orang tuaremaja) terus ke $\eta_{4}$ (kesejahteraan subjektif remaja) dengan besar efek tidak langsung sebesar $\beta 32 \times \beta 43$ atau $(0,14) \times(0,63)$ sama dengan 0,0882 . Hasil tersebut menunjukkan bahwa variabel laten kesejahteraan subjektif remaja dijelaskan secara tidak langsung sebesar 8,82 persen oleh variabel laten karakteristik keluarga yang dimediasi oleh peran gender orang tua-remaja.

Secara garis besar interpretasi hasil analisis SEM adalah bahwa kesejahteraan subjektif remaja dipengaruhi oleh peran gender orang tua-remaja (secara langsung), karakteristik remaja (secara langsung dan secara tidak langsung melalui peran gender), dan karakteristik keluarga (secara tidak langsung melalui peran gender orang tua-remaja). Dengan demikian, peran gender orang tuaremaja merupakan mediating variable yang sangat penting dan strategis dalam mempengaruhi kesejahteraan subjektif remaja. Kebahagiaan dan kepuasan remaja terhadap kondisi kehidupannya akan semakin meningkat apabila peran gender orang tua-remaja yang dicerminkan oleh intensitas aktivitas dan kemitraan gender dalam delapan fungsi keluarga semakin tinggi. Remaja perempuan mengalami peran gender orang tua yang lebih baik dibandingkan remaja laki-laki. Namun demikian, remaja laki-laki mempunyai kesejahteraan subjektif yang lebih tinggi dibandingkan remaja perempuan. Karakteristik keluarga yang semakin baik dalam hal pendidikan dan pendapatan orang tua akan meningkatkan peran gender orang tua-remaja dan akhirnya dapat meningkatkan kesejahteraan subjektif remaja. 


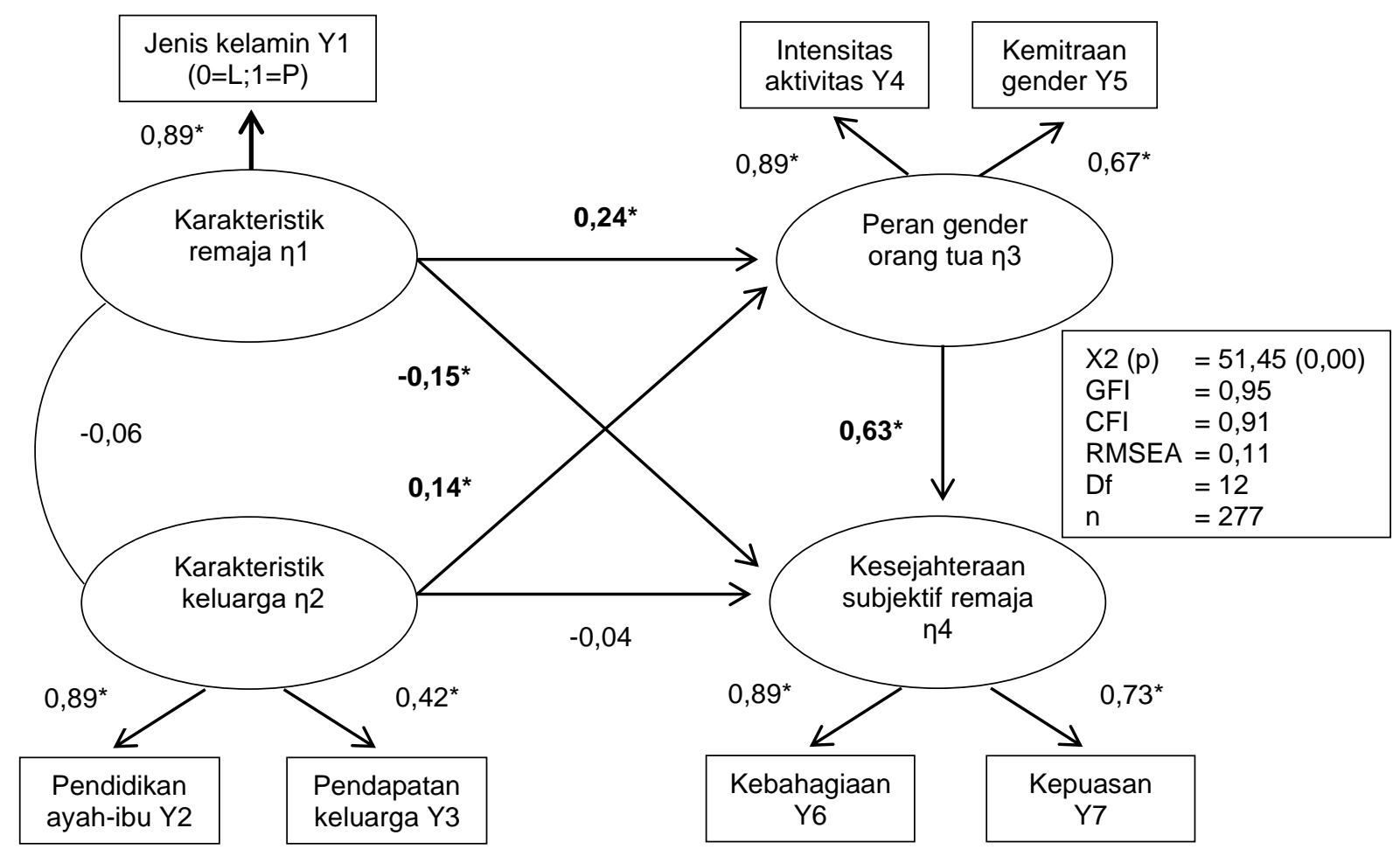

Gambar 1 Faktor-faktor yang memengaruhi kesejahteraan subjektif remaja ( $n=277)$

\section{PEMBAHASAN}

Penelitian ini memiliki beberapa temuan yang menarik untuk dibahas. Secara umum peran gender orang tua-remaja dalam fungsi keluarga belum terlaksana dengan optimal karena masih terdapat perbedaan perlakuan orang tua terhadap remaja laki-laki dan perempuan. Peran gender orang tua-remaja secara total menunjukkan lebih berfokus pada remaja perempuan dibandingkan dengan remaja lakilaki. Hasil ini mendukung penelitian sebelumnya bahwa jenis kelamin memengaruhi pelaksanaan fungsi keluarga (Stuart \& Jose, 2012). Srinovita, Hastuti, dan Muflikhati (2012) menjelaskan bahwa perkembangan dan sifat fisik yang berbeda pada anak perempuan dan laki-laki memengaruhi ayah dan ibu dalam pelaksanaan fungsi keluarga. Selain itu, remaja laki-laki memiliki kecenderungan komunikasi yang kurang terbuka dengan orang tua yang memengaruhi proses pelaksanaan fungsi keluarga (Puspitawati \& Kusumawati, 2018).

Intensitas aktivitas fungsi keluarga secara umum belum terlaksana optimal karena orang tua lebih intens dalam menjalankan fungsi keluarga pada remaja perempuan daripada laki-laki. Hasil ini sejalan dengan penelitian sebelumnya yang menjelaskan hubungan antara remaja-orang tua dipengaruhi oleh karakteristik remaja (Kraft \& Dougherty, 2012). Interaksi anak perempuan dengan orang tua yang dekat memengaruhi hubungan orang tua dan anak, termasuk pelaksanaan fungsi keluarga (Firdayanti et al., 2016). Selain itu, Srinovita et al. (2012) juga menjelaskan bahwa orang tua menganggap anak laki-laki lebih bisa mandiri dibandingkan anak perempuan sehingga memengaruhi perlakuan orang tua kepada anak.

Kemitraan gender fungsi keluarga secara umum sudah terlaksana dengan optimal karena tidak ditemukan perbedaan signifikan antar kedua kelompok remaja yang terkategori tinggi. Remaja perempuan maupun laki-laki sudah memiliki orang tua dengan kerja sama yang seimbang dalam pelaksanaan delapan fungsi keluarga. Hasil ini didukung penelitian sebelumnya bahwa suami istri yang melakukan pembagian tugas dan peran yang jelas membantu terlaksananya fungsi-fungsi keluarga (Puspitawati, 2017). Keseimbangan peran di dalam keluarga dapat terwujud melalui kesediaan suami dan istri dalam berbagi peran secara adil (Anwar, 2014). Namun, uji beda subdimensi menemukan adanya perbedaan signifikan pada kemitraan gender fungsi cinta kasih. Artinya, orang tua memiliki kerja sama yang lebih seimbang dalam menjalankan fungsi cinta kasih pada remaja perempuan. Hasil ini didukung oleh penelitian sebelumnya bahwa adanya konsep maskulin dan feminin yang melekat pada perempuan dan laki-laki menjadikan peran yang dijalaninya berbeda 
(Puspitawati, 2017). Cinta kasih identik dengan peran feminin sehingga menyebakan orang tua lebih seimbang dalam memberikan fungsi tersebut pada remaja perempuan.

\begin{abstract}
Kesejahteraan subjektif remaja menggambarkan bahwa kedua kelompok remaja sudah sangat puas dan bahagia. Hal ini sejalan dengan penelitian Navarro et al. (2017) bahwa elemen kunci kesejahteraan subjektif menurut remaja yaitu berkaitan dengan kasih sayang dan sikap, hubungan dengan keluarga dan teman, serta terbebas dari masalah. Selain itu, tingginya tingkat kesejahteraan subjektif diduga karena mayoritas remaja berlatar belakang keluarga dengan status sosial ekonomi yang baik. Hasil ini didukung penelitian Azizan, Mahmud, dan Rambli, (2018) bahwa salah satu faktor yang meningkatkan kesejahteraan subjektif ialah status sosial ekonomi. Hasil Independent T-Test menunjukkan kesejahteraan subjektif antara remaja laki-laki dan perempuan tidak berbeda signifikan. Menurut Eryilmaz (2011), hal ini terjadi karena kesejahteraan subjektif merupakan penilaian subjektif berdasarkan pengalaman sehingga tidak dapat digunakan untuk mengukur kepuasan dan kebahagiaan berdasarkan gender.
\end{abstract}

Dimensi kepuasan menunjukkan remaja lakilaki dan perempuan sudah cukup puas dengan hidupnya. Hasil ini didukung oleh penelitian sebelumnya bahwa komunikasi positif dengan orang tua secara langsung meningkatkan kepuasan hidup remaja laki-laki maupun perempuan (Cava, Buelga, \& Musitu, 2014). Hasil penelitian juga melaporkan kepuasan kedua kelompok remaja tidak memiliki perbedaan signifikan yang sejalan dengan hasil Chui dan Wong (2015). Namun, skor kepuasan remaja perempuan sedikit lebih rendah karena sistem homeostatis remaja perempuan lebih sensitif terhadap kondisi eksternal serta adanya faktor biologis (pengaruh hormonal) dan budaya (perbedaan standar sosial untuk remaja perempuan dan laki-laki) yang membuat kepekaan remaja perempuan lebih besar (Gonzáles-Carrasco et al., 2016).

Dimensi kebahagiaan memperlihatkan capaian remaja laki-laki dan perempuan terkategori tinggi.. Temuan ini sejalan dengan penelitian sebelumnya bahwa semakin tinggi tingkat kebersyukuran remaja akan membuat remaja merasakan emosi yang positif, lebih menghargai hidup, serta merasa cukup dengan apa yang mereka miliki sehingga tidak akan merasa stres, depresi, dan merasa lebih bahagia (Wijayanti, Rahmatika, \& Listiandini, 2020). Selain itu, remaja dalam penelitian ini merasa senang saat bersama keluarga ataupun teman yang mengindikasikan bahwa kebersamaan dengan orang terdekat ataupun orang yang dicintai dapat membuat remaja bahagia (Oetami \& Yuniarti, 2011). Hasil dalam penelitian ini tidak menemukan perbedaan yang signifikan antara kedua kelompok remaja. Namun, dalam penelitian yang berbeda ditemukan bahwa indeks kebahagiaan remaja perempuan sedikit lebih tinggi yang disebabkan karena perempuan memiliki perasaaan yang lebih positif (Ronen et al., 2016).

Secara garis besar, hasil analisis model SEM pada penelitian ini dapat dikatakan cocok (fit) dengan data yang dikumpulkan (merujuk pada tit indeks di Bollen, 1989). Bukti angka item loading yang membentuk keempat variabel laten dalam penelitian ini cukup konsisten (Melby, Conger, Ge, \& Warner, 1995). Model analisis pada penelitian ini menggunakan software LISREL (Jöreskog \& Sorbom, 1999; Wiley, 1973) yang menghasilkan tabel dekomposisi efek (Bolen, 1989) yang hasilnya sangat menarik.

Karakteristik remaja secara langsung berpengaruh negatif signifikan terhadap kesejahteraan subjektif remaja. Artinya, remaja laki-laki memiliki kesejahteraan subjektif berupa kebahagiaan dan kepuasan yang lebih besar dibandingkan dengan remaja perempuan. Hasil ini diperkuat penelitian sebelumnya bahwa lakilaki memiliki self esteem dan tingkat kebahagiaan yang tinggi dibanding perempuan (Dar \& Wani, 2017). Sikap optimisme yang ditunjukkan laki-laki memengaruhi tingkat kebahagiaan dan kepuasan yang lebih besar (Jacobsen et al., 2014). Selain itu, adanya perbedaan peran sosial menjadi penyebab tingkat kebahagiaan dan kepuasan pada perempuan dan laki-laki berbeda (Amaliya, 2015).

Peran gender orang tua-remaja dalam penerapan delapan fungsi keluarga secara langsung berpengaruh dalam peningkatan kesejahteraan subjektif remaja. Orang tua yang bekerja sama dalam menjalankan fungsinya dengan optimal akan membuat remaja berhasil melewati tahap krisisnya dan menjadi pribadi yang stabil. Hasil ini mendukung temuan sebelumnya bahwa keberfungsian keluarga akan meningkatkan kesejahteraan subjektif remaja (Nayana, 2013). Irzalinda, Puspitawati, dan Muflikhati (2014) menambahkan bahwa kesejahteraan subjektif yang dimiliki anak 
dipengaruhi oleh aktivitas yang dilakukan antara orang tua dan anak serta perlindungan secara fisik yang diberikan oleh orang tua pada anaknya. Selain itu, remaja yang tinggal dengan kedua orang tua, memiliki waktu luang yang dihabiskan bersama anggota keluarga, serta memiliki kasih sayang dan keterikatan yang tinggi dengan anggota keluarga akan menjadi remaja yang paling bahagia dan puas (Gray et al., 2013).

Karakteristik remaja berpengaruh positif signifikan secara tidak langsung terhadap kesejahteraan subjektif remaja melalui peran gender orang tua-remaja. Jenis kelamin remaja memengaruhi peran gender orang tua-remaja dalam pelaksanaan delapan fungsi keluarga yang selanjutnya akan memengaruhi tingkat kesejahteraan subjektif remaja. Hasil ini mendukung penelitian-penelitian sebelumnya bahwa perbedaan orang tua dalam pelaksanaan fungsi keluarga berdasarkan sifat fisik dan karakteristik anak laki-laki dan perempuan (Srinovita et al., 2012). Selanjutnya, peran gender orang tua-remaja dalam delapan fungsi keluarga yang dilaksanakan dengan optimal akan meningkatkan kesejahteraan subjektif remaja. Hasil ini sejalan dengan penelitian sebelumnya bahwa fungsi keluarga yang dilaksanakan dengan optimal dan dengan pembagian peran yang jelas akan meningkatkan kebahagiaan dan kepuasan (Aziz, 2017; Botha \& Booysen, 2013). Kesejahteraan dalam keluarga akan tercapai melalui kerja sama pembagian peran yang adil dan setara (Rahmawaty, 2015).

Karakteristik keluarga yaitu pendidikan ayah-ibu dan pendapatan keluarga berpengaruh signifikan terhadap peningkatan kesejahteraan subjektif remaja secara tidak langsung melalui peran gender orang tua-remaja. Hasil ini didukung penelitian Siswati dan Puspitawati (2017) bahwa pendidikan suami dan istri yang semakin tinggi membuat kerja sama pembagian peran gender dan pengambilan keputusan di dalam keluarga terjalin semakin harmoni. Kemudian, peran gender dalam fungsi keluarga yang optimal akan meningkatkan kesejahteraan subjektif remaja karena menurut Van der $\mathrm{Aa}$ et al. (2010) kualitas well-being remaja yang tinggi disebabkan karena adanya family functioning yang positif yang tercipta pada keluarga dengan kondisi yang nyaman, saling mendukung, dan memiliki kedekatan secara emosi satu sama lain. Penelitian lain menyebutkan bahwa pendapatan keluarga secara langsung meningkatkan kerja sama orang tua dalam mengasuh anak (coparenting support) daripada konflik dalam mengasuh anak (coparenting conflict) sehingga keluarga dapat memiliki kepuasan yang lebih baik (Riina \& Feinberg, 2018).

Hasil penelitian ini punya keterbatasan yaitu melalui survei online, sedangkan analisis peran gender orang tua-remaja akan lebih komprehensif apabila dilakukan wawancara langsung dan mendalam kepada remaja dan juga orang tuanya. Penelitian ini menggunakan teknik non-probability voluntary sampling sehingga hasil penelitian tidak dapat digeneralisasi dan proporsi responden laki-laki dan perempuan menjadi tidak seimbang.

\section{SIMPULAN DAN SARAN}

Secara keseluruhan peran gender orang tuaremaja dalam fungsi keluarga belum terlaksana dengan optimal karena masih ada perbedaan perlakuan orang tua dalam menjalankan fungsi keluarga pada remaja laki-laki dan perempuan. Intensitas aktivitas fungsi keluarga secara keseluruhan belum terlaksana optimal karena orang tua lebih intens dalam menjalankan fungsi keluarga pada remaja perempuan dibandingkan remaja laki-laki. Namun, kemitraan gender pada fungsi keluarga sudah terlaksana dengan optimal dengan kerja sama antar orangtua yang seimbang. Kesejahteraan subjektif remaja laki-laki dan perempuan sudah memperlihatkan kondisi kepuasan dan kebahagiaan yang baik dan tidak berbeda nyata. Hasil analisis SEM menunjukkan faktorfaktor yang memengaruhi kesejahteraan subjektif remaja secara langsung yaitu karakteristik remaja dan peran gender orang tua dalam fungsi keluarga. Sementara itu, karakteristik remaja dan karakteristik keluarga memengaruhi kesejahteraan subjektif remaja secara tidak langsung melalui peran gender orang tua-remaja dalam fungsi keluarga.

Disarankan agar optimalisasi kerja sama pembagian peran orangtua dapat dilakukan dengan memperbaiki komunikasi dalam keluarga, seperti melakukan musyawarah dalam mengatasi masalah keluarga. Perlu ada sosialisasi dengan memanfaatkan media sosial atau media massa seperti iklan atau video edukasi terkait komunikasi orangtua dan anak remaj. Penelitian selanjutnya disarankan menggunakan teknik probability sampling dengan jumlah partisipan laki-laki dan perempuan yang lebih proporsional, melakukan wawancara mendalam dengan orang tua dan remaja agar data yang diperoleh lebih komprehensif, serta mempertimbangkan penelitian studi komparatif di daerah perdesaan dan perkotaan. 


\section{DAFTAR PUSTAKA}

Amaliya, R. (2015). Kebahagiaan dan gender: Tinjauan kritis tentang makna kebahagiaan ditinjau dari perspektif gender. Jurnal Psikologi dan Psikologi Islam, 12(2), 17-22. doi: 10.18860/psi.v12i2.6400.

Anwar, H. (2014). Hubungan antara otonomi kerja, orientasi peran gender keluarga, keseimbangan kerja-keluarga dengan kepuasan kerja dan kepuasan keluarga pada perempuan yang berperan ganda. Intuisi: Jurnal Psikologi Ilmiah, 6(2), 60-67. doi: 10.15294/intuisi.v6i2.13312.

Aziz, A. (2017). Relasi gender dalam membentuk keluarga harmoni: Upaya membentuk keluarga bahagia. Jurnal Harkat: Media Komunikasi Gender, 12(2), 27-37. doi: 10.15408/harkat.v13i1.7713.

Azizan, N. H., Mahmud, Z., \& Rambli, A. (2018). Measurement instrument and indicators of subjective well-being: A review paper. Journal of ASIAN Behavioural Studies, 3(11), 22-33. doi: 10.21834/jabs.v3i11.322.

Bandura, A., Caprara, G. V., Barbaranelli, C., Regalia, C., \& Scabini, E. (2011). Impact of family efficacy beliefs on quality of family functioning and satisfaction with family life. Applied Psychology, 60(3), 421-448. doi: 10.1111/j.1464-0597.2010.00442.x.

[BKKBN] Badan Kependudukan dan Keluarga Berencana Nasional. (2005). Keluarga berencana dan kesehatan produksi. Jakarta, ID: BKKBN.

[BKKBN] Badan Kependudukan dan Keluarga Berencana Nasional. (2013). Buku pegangan Kader BKR tentang 8 fungsi keluarga. Jakarta, ID: BKKBN.

Bollen, K. A. (1989). Structural Equations with Latent Variables. New York, US: John Wiley \& Sons.

Botha, F., \& Booysen, F. (2013). Family functioning and life satisfaction and happiness in South African households. Social Indicators Research, 119(1), 163-182. doi: 10.1007/s11205-0130485-6.
[BPS] Badan Pusat Statistik. Statistik Pemuda Indonesia 2019. Jakarta, ID: BPS.

Cava, M. J., Buelga, S., \& Musitu, G. (2014). Parental communication and life satisfaction in adolescence. The Spanish Journal of Psychology, 17(98), 1-8. doi: 10.1017/sjp.2014.107.

Chui, W. H., \& Wong, M. Y. (2016). Gender differences in happiness and life satisfaction among adolescents in Hong Kong: Relationships and self-concept. Social Indicators Research, 125(3), 1035-1051. doi: 10.1007/s11205-0150867-z.

Dar, A. A., \& Wani, M. A. (2017). Optimism, happiness, and self-esteem among university students. Indian Journal of Positive Psychology, 8(3), 275-279.

Dewi, E. M. P. (2014). Konsep kebahagiaan pada remaja yang tinggal di jalanan, panti asuhan, dan pesantren. Intuisi: Jurnal Psikologi IImiah, 6(1), 28-33. doi: 10.15294/intuisi.v6i1.11912.

Dewi, A. K., \& Rahayu, A. (2020). Optimisme dan keberfungsian keluarga hubungannya dengan subjective wellbeing pekerja perempuan yang work from home di Kecamatan Tambun Utara Kabupaten Bekasi. IKRA-ITH HUMANIORA: Jurnal Sosial dan Humaniora, 4(3), 1-8.

Diananda, A. (2018). Psikologi remaja dan permasalahannya. Istighna: Jurnal Pendidikan dan Pemikiran Islam, 1(1), 116-133.

doi: 10.33853/istighna.v1i1.20.

Diener, E. (1984). Subjective well-being. Psychological Bulletin, 95(3), 542-575. doi: 10.1037/0033-2909.95.3.542.

Eryilmaz, A. (2011). Satisfaction of needs and determining of life goals: A model of subjective well-being for adolescents in high school. Educational Science: Theory and Practice, 11(4), 1757-1764.

Fatimaningsih, E. (2013). Memahami fungsi keluarga dalam perlindungan anak. Jurnal Sosiologi, 17(2), 77-88.

Firdayanti, Lubis, D. P., Puspitawati, H., Susanto, D. (2016). Komunikasi remaja dengan ayah masih minim: Studi pada siswa SMA di Kota Bogor. Jurnal IImu Keluarga dan Konsumen, 9(2). 124135. doi: 10.24.156/jikk.2016.9.2.124. 
Gonzáles-Carrasco, M., Casas, F., Malo, S., Viñas, F., \& Dinisman, T. (2016). Change with age in subjective wellbeing through the adolescent years: Differences by gender. Journal of Happiness Studies, 18(1), 63-88. doi: 10.1007/s10902-016-9717-1.

Gray, R. S., Chamratrithirong, A., Pattaravanich, U., \& Prasartkul, P. (2013). Happiness among adolescent students in Thailand: Family and nonfamily factors. Social Indicator Research, 110(2), 703-719. doi: 10.1007/sl 1205-011-9954-y.

Hastuti, R. Y., \& Baiti, E. N. (2019). Hubungan kecerdasan emosional dengan tingkat stress pada remaja. Jurnal IImiah Kesehatan, 8(2), 84-93.

Herawati, T., Krisnatuti, D., Pujihasvuty, R., \& Latifah, E. W. (2020). Faktor-faktor yang memengaruhi pelaksanaan fungsi keluarga di Indonesia. Jurnal IImu Keluarga dan Konsumen, 13(3), 213227. doi: 10.24156/jikk.2020.13.3.213.

Hills, P., \& Argyle, M. (2002). The oxford happiness questionnaire: A compact scale for the measurement of psychological well-being. Personality and Individual Differences, 33(7), 10731082. doi: 10.1016/S01918869(01)00213-6.

Hurlock, E. B. (1980). Psikologi perkembangan: Suatu pendekatan sepanjang rentang kehidupan ( $5^{\text {th }}$ ed.). Jakarta, ID: Erlangga.

Irzalinda, V., Puspitawati, H., \& Muflikhati, I. (2014). Aktivitas bersama orang tuaanak dan perlindungan anak meningkatkan kesejahteraan subjektif anak. Jurnal IImu Keluarga dan Konsumen, 7(1), 40-47. doi: 10.24156/jikk.2014.7.1.40.

Jacobsen, B., Lee, J. B., Marquering, W., \& Zhang, C. Y. (2014). Gender differences in optimism and asset allocation. Journal of Economic Behavior \& Organization, 107(B), 630651. doi: 10.1016/j.jebo.2014.03.007.

Jöreskog, K. G., \& Sorbom, D. (1999). Lisrel 8: New Statistical Features. Chicago, IL: Scientific Software International.

[Kemenkes] Kementerian Kesehatan. (2018). Laporan Nasional Riskesdas 2018 (Berita Resmi Statistik). Jakarta, ID: Kementrian Kesehatan Republik Indonesia.
[KPPPA] Kementerian Pemberdayaan Perempuan dan Perlindungan Anak. (2017). Indeks Komposit Kesejahteraan Anak Kabupaten/Kota 2017 (Berita Resmi Statistik). Jakarta, ID: PT. Pensta Karya.

Kraft, M., \& Dougherty, S. M. (2012). The effect of teacher-family communication on student engagement: Evidence from a randomized field experiment. Journal of Research on Educational Effectiveness, 6(3), 199-222. doi: 10.1080/19345747.2012.743636.

Krzaklewska, E. (2014). Measurements of gender equality - Analyzing dimensions, embracing areas, considering context (Working Paper No. 1.2, Jagiellonian University of Krakow, Poland).

Leth-Steensen, C., \& Gallitto, E. (2016). Testing mediation in structural equation modeling: The effectiveness of the test of joint significance. Educational and Psychological Measurement, 76(2), 339-351.

doi: 10.1177/0013164415593777.

Maintier, C., Joulain, M., \& Le Floc'h, N. (2011). To what extent do attitudes to work and subjective dimensions of nonwork contribute to men and women's life satisfaction in dual-earner pairs?. Women's Studies International Forum, 34(3), 242-250. doi: 10.1016/j.wsif.2011.02.003.

Megawangi, R. (2014). Membiarkan Berbeda: Sudut Pandang Baru Tentang Relasi Gender. Depok, ID: Indonesia Heritage Foundation.

Melby, J. N., Conger, R. D., Ge, X., \& Warner, T. D. (1995). The use of structural equation modeling in assessing the quality of marital observations. Journal of Family Psychology, 9(3), 280-293. doi: 10.1037/0893-3200.9.3.280.

Momen, M., Mehrgardi, A. A., Roudbar, M. A., Kranis, A., Pinto, R. M., Valente, B. D., ... \& Gianola, D. (2018). Including phenotypic causal networks in genomewide association studies using mixed effects structural equation models. Frontier in Genetics, 9, 455. doi: 10.3389/fgene.2018.00455.

Navarro, D., Montserrat, C., Malo, S., Gonzàlez, M., Casas, F., \& Crous, G. (2017). Subjective well-being: What do 
adolescents say?. Child \& Family Social Work, 22(1), 175-184. doi: $10.1111 /$ cfs. 12215 .

Nayana, F. N. (2013). Kefungsian keluarga dan subjective well-being pada remaja. Jurnal IImiah Psikologi Terapan, 1(2), 230-244. doi: 10.22219/jipt.v1i2.1580.

Ningsih, D. S., \& Herawati, T. (2017). The influence of marital adjustment and family funtion on family strength in early marriage. Journal of Family Science, 2(2), 23-33. doi: 10.29244/jfs.2.2.23-33.

Oetami, P., \& Yuniarti, K. W. (2011). Orientasi kebahagiaan siswa SMA, tinjauan psikologi indigenous pada siswa laki-laki dan perempuan. Humanitas, 8(2), 105-113. doi: 10.26555/humanitas.v8i2.458.

Olson, D. H. (2004). Family satisfaction scale (FSS). Life Innovations, 1-9.

Prasisti, W. D. (2016). Model kesejahteraan subjektif remaja (Disertasi, Universitas Gadjah Mada, Yogyakarta, Indonesia). Retrieved from http://etd.repository.ugm.ac.id/penelitia n/detail/99686

Putri, D. R. (2016). Peran dukungan sosial dan kecerdasan emosi terhadap kesejahteraan subjektif pada remaja awal. Indigenous: Jurnal IImiah Psikologi, 1(1), 12-22. doi: 10.23917/indigenous.v1i1.1770.

Putri, D. K., Krisnatuti, D., \& Puspitawati, H. (2019). Kualitas hidup manusia: Kaitannya dengan integritas diri, interaksi suami-istri, dan fungsi keluarga. Jurnal IImu Keluarga dan Konsumen, 12(3), 181-193. doi: 10.24156/jikk.2019.12.3.181.

Puspitawati, H. (2017). Gender dan Keluarga: Konsep dan Realita di Indonesia (Rev. ed.). Bogor, ID: IPB Press.

Puspitawati, H. (2018). Metode Penelitian Keluarga (Rev. ed.). Bogor, ID: IPB Press.

Puspitawati, H., \& Kusumawati, A. (2018). Pola komunikasi remaja dengan ibu, pola komunikasi ibu dengan guru, dan pencapaian akademik remaja. Jurnal IImu Keluarga dan Konsumen, 11(1), 25-36. doi: 10.24156/jikk.2018.11.1.25.
Raharja, B. N., \& Indati, A. (2018). Kebijaksanaan dan kepuasan hidup pada remaja. Gadjah Mada Journal of Psychology, 4(2), 96-104. doi: 10.22146/gamajop.46354.

Rahma, A., Puspitawati, H., \& Herawati, T. (2015). Pengaruh peran gender dan pemeliharaan lingkungan mikro terhadap kesejahteraan subjektif keluarga petani dataran tinggi. Jurnal IImu Keluarga dan Konsumen, 8(2), 6979. doi: 10.24156/jikk.2015.8.2.69.

Rahmawaty, A. (2015). Harmoni dalam keluarga perempuan karir: Upaya mewujudkan kesetaraan dan keadilan gender dalam keluarga. Palastren: Jurnal Studi Gender, 8(1), 1-34. doi: 10.21043/palastren.v8i1.932.

Riina, E. M., \& Feinberg, M. E. (2018). The trajectory of coparenting relationship quality across early adolescence: Family, community, and parent gender influences. Journal of Family Psychology, 32(5), 599-609. doi: $10.1037 /$ fam0000426.

Ronen, T., Hamama, L., Rosenbaum, M., \& Mishely-Yarlap, A. (2016). Subjective well-being in adolescence: The role of self-control, social support, age, gender, and familiar crisis. Journal of Happiness Studies, 17(1), 81-104. doi: 10.1007/s10902-014-9585-5.

Saputra, W. N. E., Hanifah, N., \& Widagdo, D. N. (2017). Perbedaan tingkat perilaku agresi berdasarkan jenis kelamin pada siswa sekolah menengah kejuruan Kota Yogyakarta. Jurnal Kajian Bimbingan dan Konseling, 2(4), 142-247. 10.17977/um001v2i42017p142.

Silitonga, M., Puspitawati, H., \& Muflikhati, I. (2018). Modal sosial, coping ekonomi, gejala stres suami dan kesejahteraan subjektif keluarga pada keluarga TKW. Jurnal Kesehatan Keluarga dan Pendidikan, 5(1), 20-30. doi: 10.21009/JKKP.051.03.

Siswati, \& Puspitawati, H. (2017). Peran gender, pengambilan keputusan, dan kesejahteraan keluarga dual earner. Jurnal IImu Keluarga dan Konsumen, 10(3), 169-180. doi: 10.24156/jikk.2017.10.3.169.

Sitinjak, T. J. R., \& Sugiarto. (2006). Lisrel. Yogyakarta, ID: Graha IImu. 
Srinovita, Y., Hastuti, D., \& Muflikhati, I. (2012). Pola asuh akademik, ketersediaan stimulasi, dan prestasi akademik pada remaja dengan perbedaan latar belakang pendidikan prasekolah. Jurnal IImu Keluarga dan Konsumen, 5(2), 147-156. doi: 10.24156/jikk.2012.5.2.147.

Stanescu, D. F., \& Romer, G. (2011). Family functioning and adolescents' psychological well-being in families with a TBI parent. Psychology, 2(7), 681686. doi: 10.4236/psych.2011.27104.

Stuart, J., \& Jose, P. E. (2012). The influence of discrepancies between adolescent and parent ratings of family dynamics on the well-being of adolescents. Journal of Family Psychology, 26(6), 858. doi: 10.1037/a0030056.

Sultana, A. M., Hed, N. M., \& Leh, F. C. (2013). Women's intra-household decision making power and financial resources. Advances in Environmental Biology, 7(14), 4703-4708.

Susiana, S. (2020). Kekerasan dalam rumah tangga pada masa pandemi Covid-19. (Kajian Singkat terhadap Isu Aktual dan Strategis Vol. XII, No. 24/II/Puslit/Desember/2020). Retrieved from

http://berkas.dpr.go.id/puslit/files/info_si ngkat/Info\%20Singkat-XII-24-II-P3DIDesember-2020-177.pdf.

Van der Aa, N., Boomsma, D. I., RebolloMesa, I., Hudziak, J. J., \& Bartels, M.
(2010). Moderation of genetic factors by parental divorce in adolescents' evaluations of family functioning and subjective wellbeing. Twin Research and Human Genetics, 13(2), 143-162. doi: 10.1375/twin.13.2.143.

Wendari, W. N., Badrujaman, A., \& Sismiati, A. (2016). Profil permasalahan siswa sekolah menengah pertama (SMP) negeri di Kota Bogor. Insight: Jurnal Bimbingan Konseling, 5(1), 134-139. doi: 10.21009/INSIGHT.051.19.

[WHO] World Health Organization. (2014). Mental health: A state of well being (Berita Resmi Statistik). Retrieved from https://www.who.int/healthtopics/mental-health.

Wijayanti, R., Sunarti, E., \& Krisnatuti, D. (2020). Peran dukungan sosial dan interaksi ibu-anak dalam meningkatkan kesejahteraan subjektif remaja pada keluarga orang tua bekerja. Jurnal IImu Keluarga dan Konsumen, 13(2), 125136. doi: 10.24156/jikk.2020.13.2.125.

Wijayanti, S., Rahmatika, R., Listiyandini, R. A. (2020). Kontribusi kebersyukuran dalam peningkatan kualitas hidup kesehatan pada remaja di panti asuhan. Psycho Idea, 18(1), 33-44. doi: 10.30595/psychoidea.v18i1.4123.

Wiley, D. E. (1973). The identification problem for structural equation models with unmeasured variables. Structural Equation Models in the Social Sciences, 69-83. 